\title{
Urszula Demkow
}

Zakład Diagnostyki Laboratoryjnej i Immunologii Klinicznej Warszawskiego Uniwersytetu Medycznego

Kierownik: prof. dr hab. n. med. U. Demkow

\section{Immunopatogeneza samoistnego włóknienia płuc}

\author{
Immunopathogenesis of idiopathic pulmonary fibrosis
}

Praca nie była finansowana

\begin{abstract}
The paper presents the state of the art in the pathogenesis of idiopathic pulmonary fibrosis (IPF). Both, etiology and pathogenesis of IPF are unclear. The key elements in the pathogenesis of the disease are epithelial destruction and dysregulation of the phenotype of lung fibroblasts. Currently accepted hypothesis claims that IPF is not related to underlying inflammatory state but it is rather a result of pathological interaction between pulmonary epithelium and mesenchyme followed by disturbed healing of damaged alveolar epithelial cells. The function of lung progenitor cells residing in distant lung structures is also impaired. Some scientists claim that genetic defect causes fast shortening of telomeres reducing lung properties of regeneration. According to the current knowledge, IFP is a multifactorial disease resulting from a repeated cycle of injuries followed by pathological regeneration.
\end{abstract}

Key words: idiopathic pulmonary fibrosis, pathogenesis, fibroblasts, alveolar epithelial cells

Pneumonol. Alergol. Pol. 2014; 81: 55-60

\section{Streszczenie}

Praca jest przeglądem nowoczesnej wiedzy dotyczącej patogenezy samoistnego włóknienia płuc (IPF). Zarówno przyczyna jak i patogeneza IPF są niewyjaśnione, nie istnieje spójna teoria tłumacząca przyczynę choroby. Kluczowymi elementami patogenezy IPF są: uszkodzenie komórek nabłonka pęcherzyków płucnych i dysregulacja lub zmiana fenotypu fibroblastów Obecnie uznana hipoteza głosi, że samoistne włóknienie płuc jest niezależne od zjawiska zapalenia i jest wynikiem nieprawidłowej interakcji pomiędzy komórkami nabłonka a mezenchymą oraz zaburzonego gojenia przewlekłych uszkodzeń nabłonka pęcherzyków. Nieprawidłowa jest również funkcja oddechowych komórek macierzystych i innych komórek progenitorowych rezydujących w dystalnych częściach płuc. Sugeruje się, że u chorych na IPF istnieje defekt genetyczny powodujący szybsze skracanie długości telomerów, co jest przyczyną ograniczonych zdolności tkanki płucnej do odnowy. W myśl współczesnej wiedzy IPF jest chorobą o bardzo złożonej, wieloczynnikowej etiopatogenezie i jest zainicjowane przez cykl urazów i patologicznej odnowy powtarzających się wielokrotnie.

Słowa kluczowe: samoistne włóknienie płuc, patogeneza, fibroblasty, pneumocyty

Pneumonol. Alergol. Pol. 2014; 81: 55-60

\section{Definicja i klasyfikacja idiopatycznych śródmiąższowych zapaleń płuc}

Samoistne włóknienie płuc (IPF, idiopathic pulmonary fibrosis) jest przewlekłą, postępującą chorobą o nieznanej etiologii polegającą na włóknieniu śródmiąższu płuc prowadzącym do zniszczenia ich prawidłowej struktury [1-3].

Samoistne włóknienie płuc należy do grupy idiopatycznych śródmiąższowych zapaleń płuc, do których według konsensusu ATS/ERS 2002 i 2011 zaliczono [1-3]:

Adres do korespondencji: prof. dr hab. n. med. U. Demkow, Zakład Diagnostyki Laboratoryjnej i Immunologii Klinicznej WUM, ul. Banacha 1a, 02-097 Warszawa tel.: 225991000.

10.5603/PiAP.2014.0009

Praca wpłynęła do Redakcji: 29.05.2012 r

Copyright (C) 2014 PTChP

ISSN 0867-7077 
— samoistne włóknienie płuc z dominującym obrazem morfologicznym zwykłego śródmiąższowego zapalenia/włóknienia płuc (UIP, usual interstitial pneumonia);

- ostre śródmiąższowe zapalenie płuc (AIP, acute interstitial pneumonia) z histologicznymi cechami DAD (diffuse alveolar damage);

— złuszczające śródmiąższowe zapalenie płuc (DIP, desquamative interstitial pneumonia);

- nieswoiste śródmiąższowe zapalenie płuc (NSIP, nonspecific interstitial pneumonia);

- organizujące się samoistne zapalenie płuc (COP, cryptogenic organizing pneumonia);

- zapalenie oskrzelików towarzyszące chorobie śródmiąższowej (RB-ILD, bronchiolitis associated interstitial lung disease);

- limfocytarne śródmiąższowe zapalenie płuc (LIP, lymphoid interstitial pneumonia).

Poszczególne postaci idiopatycznych śródmiąższowych zapaleń płuc, różnią się rokowaniem oraz odpowiedzią na leczenie [1, 3].

Termin IPF zwykle jest zastrzeżony dla chorych, u których typ zmian histopatologicznych jest charakterystyczny dla UIP [1]. Te zaś w badaniu histologicznym płuc charakteryzują nieregularnie rozmieszczone ogniska włóknienia, zapalenia, zmiany o typie plastra miodu i prawidłowego miąższu płuca [1-3]. Obecność ognisk fibroblastycznych jest niezbędnym elementem rozpoznania w badaniu histopatologicznym [1-3]. Według ostatnich wytycznych, rozpoznanie UIP jest możliwe bez wykonywania biopsji płuca, na podstawie typowego obrazu w tomografii o wysokiej rozdzielczości.

Rozpoznanie IPF wymaga wykluczenia innych form śródmiąższowych zapaleń płuc oraz chorób śródmiąższowych o znanej przyczynie (na przykład po ekspozycjach na czynniki środowiskowe, po lekach, w przebiegu chorób układowych) [3].

\section{Etiologia IPF}

Zarówno etiologia, jak i patogeneza IPF pozostają niewyjaśnione. Już sama definicja choroby zawiera termin „samoistne”, co w praktyce oznacza, że jeśli znamy przyczynę choroby, to rozpoznanie IPF jest wykluczone [1-3]. Niewątpliwie choroba jest zależna od czynników zewnętrznych, o czym świadczy między innymi powiązanie między częstością występowania IPF a paleniem tytoniu, jakkolwiek nie istnieje spójna teoria dotycząca udziału dymu tytoniowego w patogenezie choroby [1-3].

\section{Zapalenie w IPF}

Włóknienie polega na zjawisku ogniskowej ekspansji fibroblastów w miąższu płuc i nadmiernej akumulacji produkowanych przez nie białek macierzy zewnątrzkomórkowej (głównie kolagenu) [4]. Kluczowymi elementami patogenezy IPF są: uszkodzenie komórek nabłonka pęcherzyków płucnych i zaburzenie funkcji lub zmiana fenotypu fibroblastów [4-7]. W zapoczątkowaniu i rozprzestrzenieniu się procesu włóknienia niewielką rolę mogą odgrywać komórki zapalne [5-7]. Przez długi czas sądzono, że włóknienie u chorych na IPF jest następstwem przetrwałej reakcji zapalnej z udziałem pobudzonych makrofagów pęcherzykowych, neutrofilów, eozynofilów, limfocytów T i B, bazofilów [5, 8]. Ta koncepcja uzasadniła próby leczenia przeciwzapalnego oraz poszukiwanie markerów zapalenia jako czynników prognostycznych. W świetle współczesnej wiedzy wydaje się jednak, że w IPF, przeciwnie do wielu innych chorób śródmiąższowych, zapalenie stanowi jedynie tło dla toczącego się włóknienia, które jest odpowiedzią na bezpośrednie uszkodzenie komórek nabłonka pęcherzyków płucnych o nieznanej przyczynie $[4,7,8]$. Dlatego leczenie przeciwzapalne i immunosupresyjne jest nieskuteczne u chorych na IPF [3].

Obecnie uznana hipoteza głosi, że samoistne włóknienie płuc jest wynikiem nieprawidłowej interakcji pomiędzy komórkami nabłonka a komórkami podścieliska miąższu płuca oraz zaburzonego gojenia przewlekłych uszkodzeń nabłonka pęcherzyków, przy nieobecnych lub słabo wyrażonych zmianach zapalnych [7-10].

Włóknienie jest zawsze następstwem uszkodzenia. Każde uszkodzenie tkanek w ustroju, zapoczątkowuje proces gojenia, czyli wytwarzania włóknistej blizny z włókien kolagenowych produkowanych przez fibroblasty $[5,7,10]$. Włóknienie miąższu płuca także jest skutkiem pobudzenia fibroblastów oraz tworzenia nieprawidłowych złogów kolagenu odpornych na degradację. Złożoność budowy anatomicznej i histologicznej płuc jest przyczyną istotnych trudności lub nawet całkowitej niemożności odbudowy prawidłowej struktury po masywnym uszkodzeniu. Jeśli prawidłowa odnowa jest niemożliwa, uszkodzone miejsca wypełniają się patologiczną tkanką włóknistą $[3,5,7,10]$.

\section{Komórki macierzyste układu oddechowego w IPF}

W przypadku uszkodzeń miąższu płuca prawidłowa odnowa zaczyna się od pobudzenia komórek macierzystych (respiratory stem cells) układu 
oddechowego i innych komórek progenitorowych rezydujących w obwodowych częściach płuc (na pograniczu oskrzelików oddechowych i pęcherzyków płucnych) [11-13]. Są one pozostałością po rozwojowych liniach komórek zapoczątkowujących powstanie płuc w życiu płodowym albo pochodzą z krążących komórek macierzystych [13-15]. Komórki macierzyste układu oddechowego są źródłem, z którego pochodzą komórkowe elementy służące do naprawy pęcherzyków płucnych, oskrzelików, oskrzeli i tchawicy [12-17]. W przypadku uszkodzeń komórki macierzyste proliferują i migrują do miejsc uszkodzeń oraz różnicują się do komórek nabłonka, co doprowadza do reepitelializacji, a następnie do odbudowy prawidłowej struktury płuc [11, 12, 15, 17]. Do odnowy niezbędny jest udział czynników wzrostowych: FGF10 (fibroblast growth factor 10), BMP4 (bone morphogenic protein 4), TGF- $\beta$ (transforming growth factor beta), PDGF (plateletderived growth factor) i Wnt signaling [11, 12, 15]. Komórki macierzyste układu oddechowego rezydujące $w$ płucach nie są dokładnie scharakteryzowane [13, 15, 17]. Różnorodność i złożoność struktury płuc wskazuje na fakt istnienia licznych, rozproszonych w układzie oddechowym komórek progenitorowych [13, 15-17]. Dokładniejsze scharakteryzowanie tych komórek umożliwi lepsze poznanie morfogenezy i procesu regeneracji miąższu płuca [12, 13, 15]. Mezenchymalne komórki progenitorowe płuc posiadają enzym telomerazę, odpowiedzialny za utrzymanie długości telomerów [18, 19]. Skrócenie telomerów wiąże się ze słabszą odnową komórkową, starzeniem się komórek i całego organizmu [18, 19]. Znaczące skrócenie telomerów może być powiązane ze zmniejszoną zdolnością nabłonka pęcherzyków płucnych do odnowy. Sugeruje się, że u chorych na IPF istnieje defekt genetyczny powodujący szybsze skracanie długości telomerów co jest przyczyną ograniczonych, w porównaniu z osobami zdrowymi, zdolności miąższu płucnego do odnowy [18, 19]. Hipotezę tę w pewien sposób potwierdzałby fakt częstszego występowania IPF u osób powyżej 6. dekady życia, a więc w okresie fizjologicznego starzenia się płuc. Wykazano również, że istnieje powiązanie pomiędzy czynnikami sprzyjającymi włóknieniu a aktywnością telomerazy $[18,19]$. Wyniki tego typu badań pozwalają na definiowanie IPF zgodnie ze współczesną wiedzą jako choroby, której podłożem jest przedwczesne starzenie się komórek macierzystych układu oddechowego, powiązane z nieprawidłową reepitelializacją pęcherzyków płucnych po uszkodzeniu $[5,7,8,18,19]$.

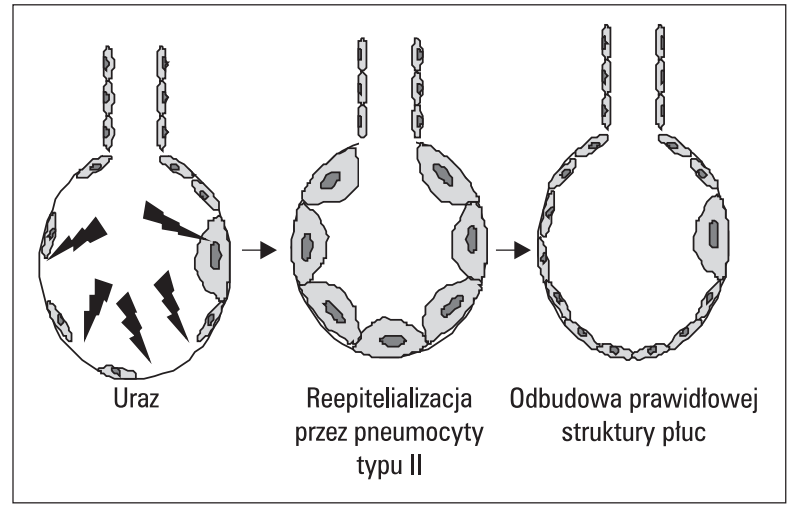

Rycina 1. Pęcherzyki płucne po uszkodzeniu, prawidłowa odbudowa

Figure 1. Pulmonary alveoli after injury, normal repair

\section{IPF - etapy patogenezy}

Prawidłowa regeneracja pęcherzyków płucnych po uszkodzeniu polega na reepitelializacji, początkowo pneumocytami typu II, które następnie różnicują się do pneumocytów typu I $[4,10,14]$ (ryc. 1). U chorych na IPF proces reepitelializacji jest zaburzony $[14,15]$. W wyniku uszkodzenia nabłonka pęcherzyków płucnych o nieznanej przyczynie, dochodzi do odsłonięcia błony podstawnej [4, 9, 10, 14]. Naga błona podstawna albo zostaje przerwana, albo ulega pofałdowaniu i tworzy głębokie wpuklenia do światła pęcherzyków płucnych [20-23]. Czynniki degradujące błonę podstawną (gelatynazy) są produkowane przez patologiczne miofibroblasty [20-23]. Uszkodzenie błony podstawnej oraz nieznany defekt pneumocytów uniemożliwiają prawidłową odnowę [7, 22-24]. Fibroblasty i miofibroblasty ze śródmiąższu płuc migrują do wnętrza pęcherzyków przez ogniskowe uszkodzenia błony podstawnej [20-23]. Zmodyfikowane fibroblasty i miofibroblasty proliferują i produkują białka macierzy zewnątrzkomórkowej w przestrzeniach wewnątrzpęcherzykowych, formując charakterystyczne dla UIP ogniska fibroblastyczne [20-23]. Złogi macierzy wewnątrzkomórkowej zawierają fibronektynę, tenascynę, glikozaminoglikany dekorynę i hialuroniany [21-23]. Substancje te dobrze chłoną wodę, powodując lokalne mikroobrzęki w obrębie patologicznej tkanki. Fuzja struktur pęcherzykowych powiązana z włóknieniem wewnątrzpęcherzykowym prowadzi do przebudowy miąższu płuca [20, 21, 23, 25].

\section{IPF — prawdopodobna sekwencja zdarzeń}

Nieprawidłową odbudowę pęcherzyków płucnych w IPF przedstawiono na rycinie 2. Prawdopodobna sekwencja zdarzeń: 


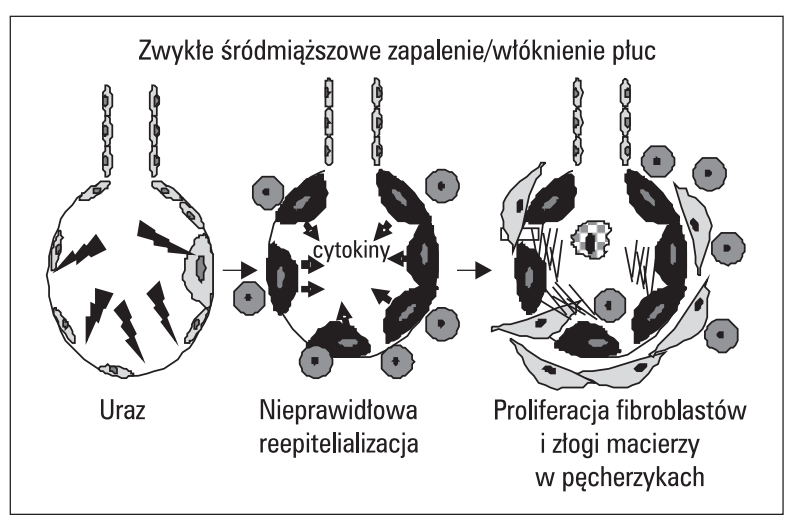

Rycina 2. IPF, pęcherzyki płucne po uszkodzeniu, nieprawidłowa odnowa

Figure 2. IPF, pulmonary alveoli after injury, pathological repair

1. Uszkodzenie nabłonka.

2. Nieprawidłowa reepitelializacja z uszkodzeniem błony podstawnej przez gromadzące się wokół pęcherzyków miofibroblasty.

3. Rozrost pneumocytów typu II, zmiana ich fenotypu i produkcja czynników sprzyjających włóknieniu.

4. Limfoproliferacja i aktywacja limfocytów produkujących czynniki profibrotyczne.

5. Tworzenie ognisk fibroblastów (miofibroblastów ) w miąższu płuca i w pęcherzykach.

6. Odkładanie się złogów macierzy w śródmiąższu i w pęcherzykach.

7. Zarastanie pęcherzyków.

\section{Fibroblasty i białka macierzy zewnątrzkomórkowej w IPF}

Fibroblasty miąższu płucnego u chorych na IPF różnią się od fibroblastów zdrowych osób [20, 21, 23]. Posiadają one fenotyp powiązany ze zwiększoną produkcją włókien kolagenowych („fenotyp produkcyjny”) [20, 21]. Różnice są widoczne już na poziomie genów [21]. Grupy genów powiązanych z metabolizmem komórki i z regulacją cyklu komórkowego aktywne w IPF są inne niż u zdrowych [20, 21]. W IPF nadmiar włókien kolagenowych jest odkładany w sposób chaotyczny w obrębie płuc. Zmodyfikowane fibroblasty i miofibroblasty proliferują oraz produkują białka macierzy zewnątrzkomórkowej w przestrzeniach powietrznych pęcherzyków [20-25]. Ogniska fibroblastyczne nie są patognomoniczne dla IPF, ale ich obecność jest niezbędna w celu rozpoznania IPF i dlatego stanowią ważne kryterium diagnostyczne [3, 22]. Zmienione fibroblasty w IPF pochodzą z różnicowania prawidłowych fibroblastów rezydujących w płucach, z rekrutacji krążących prekursorów fibroblastów (fibrocytów) do płuc oraz z przekształcenia komórek nabłonkowych płuc w fibroblasty o patologicznym fenotypie [25]. Zarówno wewnątrzpęcherzykowe, jak i śródmiąższowe fibroblasty syntetyzują białka macierzy zewnątrzkomórkowej: kolagen, fibronektynę, włókna elastyny i proteoglikany i inne $[22,24,26]$. Aktywowany TGF- $\beta$ w obecności białek macierzy i metabolitów stresu jest uważany za główny czynnik stymulujący powstanie miofibroblastów [26]. Zbyt intensywna stymulacja TGF- $\beta$ w życiu pozapłodowym prowadzi do rozwoju agresywnego i postępującego włóknienia [27]. Nadmiar TGF- $\beta$ może być uwalniany przez makrofagi pęcherzykowe oraz inne pobudzone komórki układu odpornościowego w płucach. $\mathrm{W}$ takiej sytuacji TGF- $\beta$ powoduje zmianę fenotypu fibroblastów i ich przekształcenie do miofibroblastów [27]. Fibroblasty okołonaczyniowe i okołooskrzelowe oraz krążące fibrocyty u chorych na IPF również zmieniają swój fenotyp, stając się miofibroblastami. Sugeruje się, że komórki nabłonka także mogą ulec przekształceniu w komórki mezenchymalne, stając się prekursorami miofibroblastów [27]. Ponieważ miofibroblasty w płucach mogą pochodzić z kilku źródeł, ich ekspansja w uszkodzonych płucach może mieć odmienną patogenezę u różnych chorych, zależąc, być może, w jakimś stopniu od typu pierwotnego uszkodzenia płuc [24, 25]. Proces generacji miofibroblastów pozostaje pod kontrolą także innych rodzin cytokin i czynników wzrostowych działających podobnie do rodziny TGF- $\beta$ [26, 27]. Czynniki wzrostowe pobudzają miofibroblasty do produkcji białek macierzy (kolagenu) oraz wzmagają produkcję metaloproteinaz i ich inhibitorów, chemotaksję i angiogenezę [22-24]. Główne czynniki wzrostowe biorące udział w patogenezie włóknienia płuc to IGF-1 (insulin-like growth factor 1), PDGF, CTGF (connective tissue growth factor) [27, 28]. Właściwe zrównoważenie sygnałów ze strony różnych mediatorów warunkuje prawidłowy rozwój płuc w życiu płodowym oraz prawidłową ich regenerację po urodzeniu [5, 16]. Inaczej mówiąc, wszystkie sygnały muszą być odpowiednio silne i odpowiednio zrównoważone. Presja ewolucyjna do zachowania takiej homeostazy jest ogromna i wiele mechanizmów regulacyjnych uzupełnia się, natomiast przesunięcie równowagi w jakimkolwiek kierunku prowadzi do patologii.

\section{Macierz zewnątrzkomórkowa}

W prawidłowym miąższu płuca produkcja i układ białek macierzy są skoordynowane, co warunkuje prawidłową strukturę płuc. Do struk- 
tur macierzy zewnątrzkomórkowej należy błona podstawna pęcherzyków, która zakotwicza komórki, nadaje właściwy kształt pęcherzykom i uczestniczy w komunikacji pomiędzy komórkami [5, 11]. Inne struktury macierzy zewnątrzkomórkowej tworzą śródmiąższ płuc. Macierz śródmiąższowa jest zbudowana z polisacharydów oraz włóknistych białek wypełniających przestrzenie pomiędzy komórkami, podczas gdy błona podstawna to płaska powierzchnia, na której spoczywają komórki nabłonka [5, 20]. Białkowe komponenty błony podstawnej to laminina, entaktyna/nidogen, kolagen typu IV, perlekan, i fibromodulina [5, 20]. Złogi macierzy zewnątrzkomórkowej chłoną wodę, gdyż zawierają glikozaminoglikany, hialuroniany. Brak lub nieprawidłowa interakcja pomiędzy komórkami nabłonka pęcherzykowego a strukturami błony podstawnej prowadzi do zaburzeń rozwojowych płuc (jeśli taka sytuacja występuje podczas rozwoju embrionalnego) lub zaburzeń regeneracji miąższu płuca po uszkodzeniu w późniejszych etapach życia $[9,10]$. Przebudowa tkankowa jest zależna nie tylko od syntezy białek macierzy zewnątrzkomórkowej, ale również od funkcji czynników degradujących macierz - metaloproteinaz pozostających pod kontrolą tkankowych inhibitorów (TIMP, matrix metalloproteinase tissue inhibitor) $[10,20]$. W IPF występuje brak równowagi pomiędzy działaniem metaloproteinaz i ich inhibitorów [10, 20]. Niektóre prace sugerują również pobudzenie lokalnej aktywności prokoagulacyjnej i antyfibrynolitycznej, ale nie jest jasne, czy jest to zjawisko istotne w patogenezie choroby, czy tylko fizjologiczna reakcja na toczący się proces uszkadzania i naprawy [28].

\section{IPF - hipoteza wielu uderzeń}

Wielu autorów podkreśla znaczenie różnorodnych mechanizmów działających wspólnie w patogenezie włóknienia $[8,14,18,29-31]$. Układ krzepnięcia, układ oksydanty/antyoksydanty, zjawisko zaburzonej apoptozy komórek, czynniki zapalne, angiogeneza i przebudowa naczyniowa, czynniki wzrostowe, surfaktant i czynniki regulujące białkami macierzy są powiązane ze zjawiskiem włóknienia u zwierząt [29-31]. Współzależności pomiędzy różnymi szlakami metabolicznymi oraz interakcje pomiędzy różnymi typami komórek są coraz lepiej poznawane. Aktywacja różnych ścieżek sygnałowych powoduje zachwianie równowagi czynników pro i antyfibrotycznych oraz rozregulowanie interakcji pomiędzy różnymi typami komórek [6, 8].

W myśl współczesnej wiedzy IPF jest chorobą o bardzo złożonej, wieloczynnikowej etiopatogenezie [8, 14, 18, 31]. Rozumienie tej choroby jako następstwa aktywacji indywidualnych mediatorów czy szlaków jest nieprawidłowe. Dowodzi tego nieskuteczność terapii IPF skupionej zazwyczaj na próbie wyłączenia pojedynczego mediatora lub mechanizmu. Model wielościeżkowy pozwala znieść te ograniczenia i skupić się na kompleksowości choroby. Podejście to może ułatwić odkrycie skutecznego postępowania terapeutycznego w tej jednostce chorobowej. Istotnym aspektem przyszłego leczenia IPF będzie zapewne jego indywidualizacja oparta na identyfikacji dominującej u danego chorego ścieżki patogenetycznej (terapia celowana).

\section{Podsumowanie}

Samoistne włóknienie płuc jest chorobą obarczoną bardzo złym rokowaniem, średni czas przeżycia od rozpoznania wynosi około 3 lat. Dotychczas stosowane metody leczenia są nieskuteczne. Brak efektu leczenia przeciwzapalnego i immunosupresyjnego dowodzi, że udział typowej reakcji zapalnej w patogenezie choroby jest niewielki. Dlatego prowadzone są intensywne badania nad patogenezą włóknienia u chorych na IPF. Wyniki tych badań umożliwią być może zastosowanie leczenia celowanego, skierowanego przeciwko dominującemu mechanizmowi patogenetycznemu włóknienia w indywidualnych przypadkach.

\section{Konflikt interesów}

Autorka nie zgłasza konfliktu interesów.

\section{Piśmiennictwo:}

1. Myers J.L, Katzenstein A.L. Beyond a consensus classification for idiopathic interstitial pneumonias: progress and controversies. Histopathology 2009; 54: 90-103.

2. American Thoracic Society/European Respiratory Society International. Multidisciplinary consensus classification of the idiopathic interstitial pneumonias. Am. J. Respir. Crit. Care Med. 2002; 165: 277-304.

3. ATS/ERS/JRS/ALAT Committee on Idiopathic Pulmonary Fibrosis An Official ATS/ERS/JRS/ALAT Statement: Idiopathic Pulmonary Fibrosis: Evidence-based Guidelines for Diagnosis and Management. Am. J. Respir. Crit. Care Med. 2011; 183: 788-824.

4. Todd N.W., Luzina I.G., Atamas S.P. Molecular and cellular mechanisms of pulmonary fibrosis. Fibrogenesis Tissue Repair. 2012; 5: 11.

5. Shi W., Xu J., Warburton D. Development, repair and fibrosis: what is common and why it matters. Respirology 2009; 14: 656-665.

6. Mehrad B. Burdick M.D., Zisman D.A., Keane M.P., Belperio J.A., Strieter R.M. Circulating peripheral blood fibrocytes in human fibrotic interstitial lung disease Biochem. Biophys. Res. Commun. 2007; 353: 104-108.

7. Sakai N., Tager A.M. Fibrosis of two: epithelial cell-fibroblast interactions in pulmonary fibrosis. Biochim. Biophys. Acta. 2013; 1832: 911-921.

8. Maher T.M., Wells A.U., Laurent G.J. Idiopathic pulmonary fibrosis: multiple causes and multiple mechanisms? Eur. Respir. J. 2007; 30: 835-839. 
9. Eblaghie M.C., Reedy M., Oliver T., Mishina Y., Hogan B.L. Evidence that autocrine signaling through Bmpr1a regulates the proliferation, survival and morphogenetic behavior of distal lung epithelial cells. Dev. Biol. 2006; 291: 67-82.

10. Lwebuga-Mukasa J.S. Matrix-driven pneumocyte differentiation. Am. Rev. Respir. Dis. 1991; 144: 452-457.

11. Warburton D., Bellusci S., De Langhe S. i wsp. Molecular mechanisms of early lung specification and branching morphogenesis. Pediatr. Res. 2005; 57: 26-37.

12. Warburton D., Perin L., Defilippo R., Bellusci S., Shi W. Driscoll B. Stem/Progenitor cells in lung development, injury repair, and regeneration. Proc. Am. Thorac. Soc. 2008; 5: 703-706.

13. Kotton D.N., Fine A. Lung stem cells. Cell Tissue Res. 2008; 331: 145-56.

14. Malli F., Koutsokera A., Paraskeva E. i wsp. Endothelial progenitor cells in the pathogenesis of idiopathic pulmonary fibrosis: an evolving concept. PLoS One. 2013; 8: e53658.

15. Green M.D., Huang S.X., Snoeck H.W. Stem cells of the respiratory system: From identification to differentiation into functional epithelium. Bioessays 2013; 35: 261-270.

16. Wu M., Wei Y.Q. Development of respiratory stem cells and progenitor cells. Stem Cells Dev. 2004; 13: 607-613.

17. Emura M. Stem cells of the respiratory tract. Paediatr. Respir Rev. 2002; 3: 36-40

18. Cronkhite J.T., Xing C., Raghu G. i wsp. Telomere shortening in familial and sporadic pulmonary fibrosis. Am. J. Respir. Crit. Care Med. 2008; 178: 729-737.

19. Le Saux C.J., Davy P., Brampton C. i wsp. A novel telomerase activator suppresses lung damage in a murine model of idiopathic pulmonary fibrosis. PLoS One. 2013; 8: e58423.

20. Tomasek J.J., Gabbiani G., Hinz B., Chaponnier C., Brown R.A. Myofibroblasts and mechano-regulation of connective tissue remodelling. Nat. Rev. Mol. Cell Biol. 2002; 3: 349-363.
21. Larsson O., Diebold D., Fan D.H. i wsp. Fibrotic myofibroblasts manifest genome-wide derangements of translational control. PLOS ONE. 2008; 3: e3220.

22. Zhang K., Rekhter M.D., Gordon D., Phan S.H. Myofibroblasts and their role in lung collagen gene expression during pulmonary fibrosis. A combined immunohistochemical and in situ hybridization study. Am. J. Pathol. 1994; 145: 114-125.

23. Zhou Y., Huang X., Hecker L. i wsp. Inhibition of mechanosensitive signaling in myofibroblasts ameliorates experimental pulmonary fibrosis. J. Clin. Invest. 2013; 123: 1096-1108.

24. Kim K.K., Kugler M.C., Wolters P.J i wsp. Alveolar epithelial cell mesenchymal transition develops in vivo during pulmonary fibrosis and is regulated by the extracellular matrix. Proc. Natl. Acad. Sci. U. S. A. 2006; 103: 13180-13185.

25. Phillips R.J., Burdick M.D., Hong K. i wsp. Circulating fibrocytes traffic to the lungs in response to CXCL12 and mediate fibrosis. J. Clin. Invest. 2004; 114: 438-446.

26. Decologne N., Kolb M., Margetts P.J. i wsp. TGF-beta1 induces progressive pleural scarring and subpleural fibrosis. J. Immunol. 2007; 179: 6043-6051.

27. Sime P.J, Xing Z., Graham F.L., Csaky K.G., Gauldie J. Adenovector-mediated gene transfer of active transforming growth factor-beta1 induces prolonged severe fibrosis in rat lung. J. Clin. Invest. 1997; 100: 768-776.

28. Chambers R.C. Role of coagulation cascade proteases in lung repair and fibrosis. Eur. Respir. J. 2003; 22 (supl. 44): 33-35.

29. Kinnula V.L., Fattman C.L., Tan R.J., Oury T.D. Oxidative stress in pulmonary fibrosis: a possible role for redox modulatory therapy. Am. J. Respir. Crit. Care Med. 2005; 172: 417-422.

30. Thannical V.J., Horowitz J.C. Evolving concepts of apoptosis in idiopathic pulmonary fibrosis. Proc. Am. Thorac. Soc. 2006; 3: 357-363

31. Sisson T.H., Maher T.M., Ajayi I.O. i wsp. Increased survivin expression contributes to apoptosis-resistance in IPF fibroblasts. Adv. Biosci. Biotechnol. 2012; 3(6A): 657-664. 